\title{
Role of wide-angle optical coherence tomography angiography in the detection of clinically non- apparent neovascularisation in proliferative diabetic retinopathy
}

\author{
Akash Belenje, Padmaja Kumari Rani
}

Smt Kanuri Santhamma Center for Vitreoretinal Diseases, Kallam Anji Reddy Campus, LV Prasad Eye Institute, Hyderabad, India

Correspondence to Dr Padmaja Kumari Rani; rpk111@gmail.com

Accepted 10 August 2020

Check for updates

(c) BMJ Publishing Group Limited 2020. No commercial re-use. See rights and permissions. Published by BMJ.

To cite: Belenje A, Rani PK. BMJ Case Rep 2020:13:e236836 doi:10.1136/bcr-2020236836

\section{DESCRIPTION}

A 69-year-old man was referred by his physician for a routine fundus evaluation. He was known to have type 2 diabetes mellitus, hypertension and leftsided hemiparesis due to a history of stroke. Bestcorrected visual acuity was 20/25; N6 in both eyes. Fundus evaluation indicated the presence of a few microaneurysms in the posterior pole and preretinal haemorrhages, just above the arcades, in both eyes (figure $1 \mathrm{~A}, \mathrm{~B}$ ). He was imaged using wide-angle swept source optical coherence angiography (SS OCTA) $12 \times 12 \mathrm{~mm}$ field of view (PLEX Elite 9000; Carl Zeiss Meditec, Dublin, California, USA) which showed the presence of neovascular fronds hidden behind preretinal haemorrhages and adjacent capillary non-perfusion areas in both eyes (figure $2 \mathrm{~A}, \mathrm{~B}$ ).

He underwent panretinal photocoagulation in both eyes based on the diagnosis of proliferative diabetic retinopathy (PDR) with the detection of clinically non-apparent neovascularisation by wideangle SS OCTA.

Fundus fluorescein angiography (FFA) was considered the gold standard for the detection of neovascularisation. However, wide-angle OCTA has advantages over FFA as it has a widefield of view, non-invasive imaging and employs dye less visualisation techniques.

Wide-angle SS OCTA is a three-dimensional imaging modality which detects retinal neovascularisation, by observing red blood cell motion signals inside the neovascular fronds above the internal limiting membrane, and plots the neovascularisation changes in two-dimensional images. ${ }^{12}$

Wide-angle SS OCTA, with its automated segmentation techniques, has the ability to detect the presence of multiple retinal pathologies, such as capillary non-perfusion, preretinal haemorrhage and the presence of neovascularisation at different layers in the same area. This may not be clinically apparent and is often missed. ${ }^{34}$

When the simulated widefield SS OCTA field of view was placed over the ultra-widefield FFA, most eyes had comparable results in the detection of neovascularisation among the two modalities hence ultra-widefield OCTA may be the only imaging needed to manage PDR. ${ }^{56}$

Widefield colour fundus imaging and wide-angle SS OCTA can detect eyes with higher grades of diabetic retinopathy (DR) when compared with clinical examination alone. ${ }^{7}$ Better visualisation of

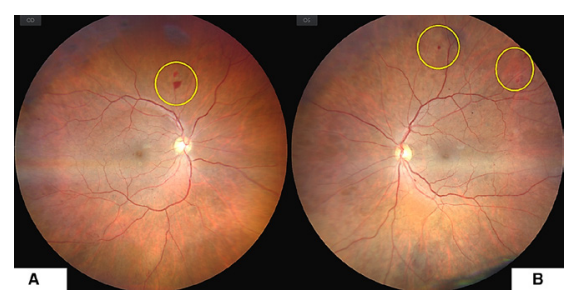

Figure $1 \quad(A, B)$ Composite fundus image of both eyes show preretinal haemorrhages with clinically nonapparent neovascularisation in the superotemporal quadrant (encircled yellow circles).

the peripheral retina using ultra-widefield imaging improves diagnosis and classification of diabetic retinopathy; hence wide-angle SS OCTA could become a routine mode of documentation in the near future. ${ }^{8}$

Widefield OCTA allowed us to correctly diagnose the patient with proliferative diabetic retinopathy. The peripheral new vessels could have been missed on clinical fundus examination alone.

Patients with multiple comorbidities are more likely to miss their follow-up appointments. They may be medically unfit to have FFA and may also be prone to dye related complications.

These patients may have a faster rate of diabetic retinopathy progression and may only return to the clinic for review when the vision has drastically deteriorated. It is, therefore, very important to diagnose and treat these patients during the same clinic visit where possible.

A patient-friendly, non-invasive and safe modality is therefore highly appropriate for use in medically unfit patients with diabetes. The wide-angle SS

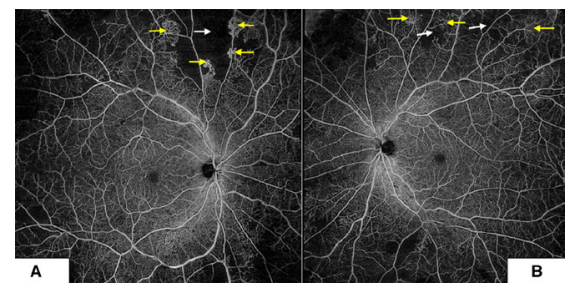

Figure $2(A, B)$ Composite wide-angle optical coherence tomography angiography image of both eyes show the presence of neovascularisation fronds beneath the preretinal haemorrhages (yellow arrows) and adjacent capillary non-perfusion areas (white arrows). 
OCTA fulfils this role by detecting peripheral diabetic neovascularisation, which will cause devastating vision loss if left untreated.

\section{Learning points}

- The presence of preretinal haemorrhages indicate the possibility of underlying clinically non-apparent neovascularisation in the proliferativediabetic retinopathy (PDR).

- Wide-angle swept source opticalcoherence angiography is a quick and non-invasive diagnostic modality in the detection of clinically non-apparent neovascularisation in PDR.

Contributors $A B$ collected images and prepared manuscript draft. PKR managed the case and edited the manuscript.

Funding The authors have not declared a specific grant for this research from any funding agency in the public, commercial or not-for-profit sectors.

Competing interests None declared.

Patient consent for publication Parental/guardian consent obtained.

Provenance and peer review Not commissioned; externally peer reviewed.
ORCID iD

Padmaja Kumari Rani http://orcid.org/0000-0001-7069-8238

\section{REFERENCES}

1 Or C, Sabrosa AS, Sorour O, et al. Use of OCTA, FA, and ultra-widefield imaging in quantifying retinal ischemia: a review. Asia Pac J Ophthalmol 2018;7:46-51.

2 de Carlo TE, Bonini Filho MA, Baumal CR, et al. Evaluation of preretinal neovascularization in proliferative diabetic retinopathy using optical coherence tomography angiography. Ophthalmic Surg Lasers Imaging Retina 2016;47:115-9.

3 Schaal KB, Munk MR, Wyssmueller I, et al. Vascular abnormalities in diabetic retinopathy assessed with SWEPT-SOURCE optical coherence tomography angiography widefield imaging. Retina 2019;39:79-87.

4 Stanga PE, Papayannis A, Tsamis E, et al. New findings in diabetic maculopathy and proliferative disease by Swept-Source optical coherence tomography angiography. Dev Ophthalmol 2016;56:113-21.

5 Russell JF, Flynn HW, Sridhar J, et al. Distribution of diabetic neovascularization on ultra-widefield fluorescein angiography and on simulated widefield OCT angiography. Am J Ophthalmol 2019;207:110-20.

6 Dalton M. Ultra wide field OCT may be the only imaging needed to manage PDR, 2019. Available: https://www.modernretina.com/view/ultra-widefield-oct-may-be-onlyimaging-needed-manage-pdr

7 Manjunath V, Papastavrou V, Steel DHW, et al. Wide-Field imaging and OCT vs clinical evaluation of patients referred from diabetic retinopathy screening. Eye 2015:29:416-23.

8 Ghasemi Falavarjani K, Wang K, Khadamy J, et al. Ultra-wide-field imaging in diabetic retinopathy; an overview. J Curr Ophthalmol 2016;28:57-60.

Copyright 2020 BMJ Publishing Group. All rights reserved. For permission to reuse any of this content visit

https://www.bmj.com/company/products-services/rights-and-licensing/permissions/

BMJ Case Report Fellows may re-use this article for personal use and teaching without any further permission.

Become a Fellow of BMJ Case Reports today and you can:

- Submit as many cases as you like

- Enjoy fast sympathetic peer review and rapid publication of accepted articles

- Access all the published articles

- Re-use any of the published material for personal use and teaching without further permission

Customer Service

If you have any further queries about your subscription, please contact our customer services team on +44 (0) 2071111105 or via email at support@bmj.com.

Visit casereports.bmj.com for more articles like this and to become a Fellow 